\title{
Desassossego por vir
}

*Luis Estrela de Matos

(A Maurice)

Precisaria

que este desassossego

não fosse só

meu

e teu tonicamente nosso

e que fosse um alguém, alguém, alguém

alguém fala, alguém come, alguém cospe, alguém dorme, alguém fode algo bernardizasse tantos

além-soaresmente de uma Baixa

da linguagem pós-desassossego

e isto de fazer envelopes

e isto de enumerar páginas

e isto de uma genética quase crítica

de almas nervosamente azuis

porque intraduzíveis

isto parece lodo, parece asco, parece redondezas

Parece periferia 
As massas realmente chegaram aos biscoitos finos

E comem tudo que traçam pela frente

Pois tem fome de coisas

Melhor seria se o fosse

Por incontáveis desassossegos

Que eu e tu e algo e alguém nos livrasse

E nos tornasse não um livro por escrever

Mas um imenso desassossego,

Um fabuloso desassossego por vir

Blanchot, ó Blanchot

Livrai-nos deste mal...

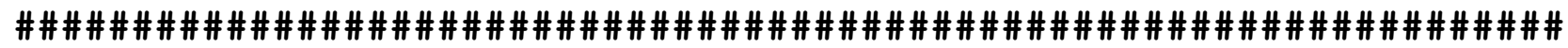

* Ensaísta, escritor, professor, e doutorando pelo programa de

Literatura Comparada da Universidade Federal Fluminense 